Dewi Mulyati dan Ali Dahwir, Perlindungan Hukum Terhadap Anak Sebagai Pelaku Kejahatan, Halaman 31-48

\title{
PERLINDUNGAN HUKUM TERHADAP ANAK SEBAGAI PELAKU KEJAHATAN
}

\author{
Dewi Mulyati ${ }^{1}$ dan Ali Dahwir ${ }^{2}$ \\ ${ }^{1}$ Fakultas Hukum, Universitas Palembang \\ E-mail : Dewi_cancer20@yahoo.com \\ ${ }^{2}$ Fakultas Hukum, Universitas Palembang \\ E-mail: dahwirali@yahoo.com,
}

\begin{abstract}
The focus of this research is to understand how the form of legal protection provided by the state to children who commit crimes. The type of research used is library research. Based on the results of the study, it is known that the form of protection for children who commit crimes is given at every stage of the juvenile criminal justice process. Starting from the arrest stage, detention stage, investigation stage, prosecution, and trial stage, as well as during the coaching period. Another form of protection is efforts to settle criminal cases outside the trial, namely children's cases are always pursued through diversion and this is required to be done at every stage of the juvenile criminal justice process. The purpose of providing legal protection to child offenders is also the implementation of respect for the perpetrators' human rights so that they are not psychologically disturbed, have legal certainty, and to avoid arbitrary and unfair treatment.
\end{abstract}

Keywords : Protection; Children; Crime

\begin{abstract}
Abstrak
Fokus penelitian ini untuk memahami bagaimana bentuk perlindngan hukum yang diberikan negara kepada anak yang melakukan kejahatan. Jenis penelitian yang dipakai adalah penelitian kepustakaan. Berdasarkan hasil penelitian diketahui bahwa bentuk perlindungan terhadap anak yang melakukan kejahatan diberikan pada setiap tahapan proses peradilan pidana anak. Mulai dari tahapan penangkapan, tahapan penahanan, tahap penyidikan, penuntutan, maupaun tahap persidangan, serta pada masa pembinaan. Bentuk perlindungan lainnya adalah upaya penyelesaian perkara tindak pidana diluar persidangan yakni perkara anak senantiasa diupayakan melalui diversi dan hal ini diwajibkan dilakukan upaya pada setiap tahapan proses peradilan pidana anak. Tujuan pemberian perlindungan hukum kepada anak pelaku kejahatan juga merupakan implementasi penghormatan hak asasi pelaku supaya psikologisnya tidak terganggu, mempunyai kepastian hukum, serta untuk menghindari perlakuan yang sewenangwenang dan tidak adil.
\end{abstract}

Kata Kunci : Perlindungan; Anak; kejahatan

\section{PENDAHULUAN}

\section{A. Latar Belakang}

Permasalahan anak merupakan permasalahan serius di Indonesia. Anak-anak merupakan generasi bangsa Indonesia. Anak-anak sangat penting bagi negara ini. Anak-anak sangatlah mudah mengikuti pengaruh yang ada, sehingga anak-anak sangat mudah terjerumus oleh kehidupan sekitar yang sangat tidak baik oleh anak-anak sekarang untuk melakukan kejahatan. 
Dewi Mulyati dan Ali Dahwir, Perlindungan Hukum Terhadap Anak Sebagai Pelaku Kejahatan, Halaman 31-48

Oleh karena anak sering melakukan kejahatan, negara selayaknya sudah harus mencari solusi mengatasi hal tersebut, dan apabila sudah terlanjut terjadi maka negara harus memberikan perlindungan hukum terhadap anakanak sebagai pelaku kejahatan. ${ }^{1}$

Anak sebagai pelaku kejahatan sampai saat ini jarang sekali diberikan perlindungan hukum secara baik dan secara komprehensive. Terkadang anak yang melakukan kejahatan tidak jarang diperlakuan yang tidak sesuai dengan aturan hukum. Padahal di dalam UU Nomor 11 Tahun 2012 tentang Sistem Peradilan Pidana Anak, menyatakan dengan jelas bahwa untuk anak yang telah melakukan kejahatan terhadap nya mendapatkan perlindungan hukum 2

Selain itu, Serafina Shinta Dewi mengemukakan tentang kenakalan remaja kian hari semakin meningkat didalam kehidupan masyarakat. Tindakan tersebut bukan hanya membuat resah orang tua anak yang melakukan pelanggaran, namun juga telah meresahkan masyarakat.

\footnotetext{
${ }^{1}$ Marjan Haposanda Sinaga, ProsesPeradilan Pidana Anak YangBerkonflik DenganHukum Dalam Rangka Pemberian Perlindungan Hukum Terhadap Anak, Skripsi Fakultas Hukum Dan Komunikasi (Semarang: Unika Soegijapranata 2018).

2 Marjan Haposanda.
}

Sehingga hal ini telah menyebabkan terganggunya keamanan, kenyamanan, dan ketertiban hidup disekitar tempat anak tersebut. Terakhir, anak-anak yang nakal tidak hanya menyebabkan kerugian terhadap orang tua akan tetapi juga terhadap masyarakat yang terdapat disekitarnya. Tindakan anak yang demikian juga telah memberikan ancaman akan masa depan bangsa serta negara. Hal ini disebabkan oleh anak yang diharapkan menjadi generasi yang akan melanjutkan pembangunan bangsa dan negara Indonesia. Berdasarkan pada hal tersebut maka, anak membutuhkan serta perlu dindungi dari perbuataan/tindakan yang dapat mengakibatkan hal buruk terhadap anak atau orang-orang di sekitar dirinya, baik dari rusaknya mental, kerugian materil maupun sosial lainnya, mengingat kondisi dan keadaan anak yang menurut kodratnya selalu tidak mampu melindungi dirinya dari berbagai tindakan berbahaya. ${ }^{3}$

Masa remaja adalah suatu masa anak-anak akan mengalami perubahan yang begitu drastis pada semua aspek, diantaranya, adanya perubahan

\footnotetext{
${ }^{3}$ Serafina S.D, Perlindungan HakAnak Pelaku Kejahatan Dalam Proses Peradilan, (Yogyakarta: Kantor Kementerian Hukum dan HAM, 2011).
} 
Dewi Mulyati dan Ali Dahwir, Perlindungan Hukum Terhadap Anak Sebagai Pelaku Kejahatan, Halaman 31-48

terhadap tubuh, perubahan emosi, kecerdasan, pandangan sosial maupun sikap kepribadian. Masa remaja merupakan masa dimana kondisi anak menjadi rapuh yang disebabkan oleh perubahan yang terjadi serta ketidak stabilan emosi, yang kadang mengarah kepada sikap perilaku dan tindakan yang dapat dianggap beracun oleh orang dewasa. ${ }^{4}$

Derasnya perubahan sosial dengan dukungan majunya teknologi menambah problematika anak. Sebagai generasi penerus, anak atau remaja seyogianya mendapat perlindungan. Itulah arti pentingnya Undang-Undang Perlindungan Anak. Namun apakah dalam tataran realitas, undang-undang tersebut telah berjalan sebagaimana mestinya. Anak merupakan suatu bagian dari kehidupan masyarakat, anak juga mempunya hak yang tidak dibedakan dengan hak-hak orang lain, untuk dilindungi dan dihormati. Secara psikis, dapat difahami bahwa seorang anak masih selalu mencari jati diri, sehingga tidak jarang mental mereka dengan mudah terguncang, yang disebabkan keadaan serta kondisi

${ }^{4}$ Gatot Supramono, HukumAcara Pengadiilan Anak,(Jakarta: Djambatan, 2007). tempat tinggal mereka. Apabila pada lingkungan anak tersebut terdapat dampak buruk, maka hal ini akan mendorong seorang anak berperilaku yang tidak baik, bahkan seorang anak dapat melakukan suatu tindakan yang melawan hukum. Sehingga hal ini merugikan diri sendiri dan masyarakat dan pada akhirnya menyebabkan mereka harus berhadapan dengan penegak hukum. ${ }^{5}$

Pencegahan yang dapat dilakukan supaya anak tidak melakukan perbuatan yang bertentangan dengan hukum merupan suatu solusi yang harus dicari bersama. Namun demikian apabila seorang anak telah terlanjut melakukan suatu tindakan yang melanggar hukum, selanjutnya bagaimana tentang proses dalam menangani atau proses pelaksanaan peradilan pidana bagi dirinya. Seorang anak yang terlanjur telah melakukan kejahatan juga sesuatu hal yang merupakan suatu permasalahan sangat serius yang harus dicarikan solusinya oleh semua kalangan, bukan hanya oleh pemerintah (aparat penegak hukum), akan tetapi oleh orang tua dan

\footnotetext{
${ }^{5}$ MediaAkademika,Volume 26 Nomor 2 April 2011
} 
Dewi Mulyati dan Ali Dahwir, Perlindungan Hukum Terhadap Anak Sebagai Pelaku Kejahatan, Halaman 31-48

masyarakat. Apakah proses peradilan terhadap anak ini telah memberikan perlindungan terhadap anak. Hal ini dikarenakan oleh seorang anak masih belum sepenuhnya dapat dimintakan pertanggungjawaban terhadap tindakan-tindakan yang telah mereka lakukan.

Selain itu, ketentuan yang termuat didalam Undang-Undang No. 11 Tahun 2012 telah mengamanatkan bahwa pada tahapan atau proses pelaksanaan dalam memeriksa dan mengadili seorang anak yang berhadapan dengan hukum pidana sebagai pelaku tindak pidana, perlu diutamakan melalui jalan diversi yang merupakan perubahan proses peradilan pidana secara formal ke penyelesaian secara kekeluargaan. Untuk itu proses peradilan hanya akan dilaksanakan sebagai upaya yang terakhir. ${ }^{6}$

Selain itu terjadinya kenakalan remaja dapat juga diakibatkan pengaruh lingkungan sekitar, khususnya lingkungan diluar keluarga. Tidak sedikit para remaja senang bermain diluar kebersamaan keluarga, mereka menghabiskan waktu bersama-

${ }^{6}$ Marjan Haposanda Sinaga. ProsesPeradilan Pidana Anak YangBerkonflik DenganHukum Dalam Rangka Pemberian Perlindungan Hukum Terhadap Anak. sama teman mereka, apakah teman dirumah, teman disekolah, maupun teman kelompok. Apabila seorang teman sebaya ada yang melakukan suatu tindakan yang salah di lingkungan mereka, maka seorang anak sering terpengaruh oleh sikapnya tanpa melakukan perhitungan sebelumna. Sikap rentan yang seperti ini merupakan implementasi perkembangan kepribadian seorang remaja. $^{7}$

Apabila melihat pada uraian tersebut di atas, dapat dilihat dari teori John Lock yang dikenal dengan teori lingkungan atau empirisme, yang memberikan pendapat tentang manusia dilahirkan kemuka bumi dalam kondisi yang suci atau tabularasa, dimana tumbuh kembangnya manusia dipengaruhi serta ditentukan oleh lingkungan sekitar, yaitu tingkat perkembangan intelektual manusia dapat di lingkungan dipengaruhi pengalaman serta suatu pengetahuan
7 Zakiah Darajat, Faktor-faktor Yang Merupakan Masalah Dalam Proses Pembinaan Generasi Muda, Kertas Kerja Pada Simposium Aspek-Aspek Hukum Masalah Perlindungan Anak .Dilihat Dari Segi Pembinaan Generasi Muda (Jakarata: DepHam RI, 1980). 
Dewi Mulyati dan Ali Dahwir, Perlindungan Hukum Terhadap Anak Sebagai Pelaku Kejahatan, Halaman 31-48

yang dapat diperoleh dari lingkungan tempat tinggal mereka. ${ }^{8}$

Cara berpikir anak ini dapat pula dibedakan, ada yang dapat berpikir secara normal dan ada pula yang tidak dapat berpikir secara normal disebabkan akalnya tidak sehat. Apabila suatu kejahatan itu yang menjadi pelakunya adalah anak maka terhadap sianak yang dapat berpikir secara normal hakim dapat menjatuhkan pidana kepadanya, sedangkan bila sebaliknya yaitu terhadap anak yang tidak dapat berpikir secara normal dapat dikembalikan kepada orang tuanya atau dimasukkan kerumah sakit jiwa untuk dirawat. ${ }^{9}$

Dari uraian diatas serta banyaknya kasus tindak pidana yang anak sebagai pelakunya, maka dalam hal ini penulis menentukan permasalahn dalam penelitian ini adalah: Bagaimanakah Perlindungan hukum terhadap Anak SebagaiPelaku Kejahatan.

\section{B. Tujuan dan Manfaat Penelitian}

Tujuan yang akan didapatkan dari hasil penelitian ini adalah untuk mengetahui bagaimana perlindungan

${ }^{8}$ A. A. Raden Cahaya Prabu, Perkembangan Taraf Inteligensia Anak (Bandung: Angkasa, 2011).

${ }^{9}$ A. A. Raden Cahaya Prabu. hukum terhadap Anak SebagaiPelaku Kejahatan. Selanjutnya adapun manfaat yang ingin didapatkan dengan penelitian ini secara teoritis adalah dapat digunakan dalam memberikan gambaran yang terjadi terhadap masalah Perlindungan hukum terhadap Anak Sebagai Pelaku Kejahatan. Lebih luas diharapkan akan memberikan sumbangan pemikiran dalam rangaka mengembangkan hukum pidana di Indonesia. Secara praktis merupakan salah satu pemikiran bagi hakim dalam menimbang serta memutuskan sekaligus perlindungan terhadap anak, khususnya pengaruh pemidanaan tersebut bagi si anak dan masyarakat. Adapun kegunaan lainnya adalah sebagai informasi dan tambahan kepustakaan bagi para praktisi, akademisi hukum.

\section{Metode Penelitian}

Dalam upaya menjawab suatu permasalahan dalam penelitian, diperlukan metode penelitian akan digunakan untuk mendapatkan sutau hasil penelitian yang tepat dan akurat. Adapun tipe penelitian adalah jenis penelitian hukum normative, yaitu dengan mengkaji berbagai peraturan perundang-undangan dan mengumpulkan data-data penunjang 
Dewi Mulyati dan Ali Dahwir, Perlindungan Hukum Terhadap Anak Sebagai Pelaku Kejahatan, Halaman 31-48

yang ada diperpustakaan. Metode pendekatan yang dilakukan adalah secara normative. Pendekatan secara normative dilakukan melalui penelaahan atas teori, konsep-konsep maupun peraturan perundangundangan yang memiliki relevansi pada permasalahan yang telah ditetapkan. Sumber data berdasarkan bahan hukum primer, dan bahan hukum sekunder adalah jenis bahan hukum yang akan memberi penjelasan tentang bahan-bahan hukum primer yang terdiri dari karya ilmiah, tulisan ilmiah, surat kabar,buku-buku hukum dan lain-lain. Prosedur pengumpulan data untuk tujuan pengumpulan data. Pada intinya dalam artikel ini, penulis menggunakan studi normatif. Studi kepustakaan(normatif) yang digunakan penulis dalam pembahasan penelitian ini adalah dalam mendapatkan datadata sekunder, terutama melalui serangkaian kegiatan, membaca, mengutip, mencatat, menelaah peraturan perundang-undangan yang memiliki relevansi dengan topik penelitian. Data yang sudah didapatkan dianalisis dengan menggunakan analisis kualitatif. penggunaan analisis ini untuk mengkaji aspek secara normatif atau aspek hukum dengan metode analisis deskriptif, yakni meliputi deskripsi deskriptif dari data yang telah dikumpulkan kemudian dihubungkan atara data yang satu satu dengan yang lainnya untuk kemudian ditarik suatu kesimpulan secara induktif.

\section{PEMBAHASAN}

\section{Perlindungan Hukum Terhadap}

\section{Anak Sebagai Pelaku Kejahatan}

Anak menurut hukum positif di Indonesia adalah anak yang belum dewasa (minderjarig/minor), di bawah umur atau anak yang berada dibawah pengampuan wali. Definisi anak dilihat secara kronologis karena hukum berbeda-beda menurut tempat, waktu dan tujuan. Sehingga hal ini adapt mempengaruhi batasan-batasan tentang definisi yang pakai untuk menentukan usia anak dewasa. ${ }^{10}$

Anak adalah seseorang yang dilahirkan melalui hubungan yang dilakukan antara seorang pria dan seorang wanita. Hubungan antara seorang pria dan seorang wanita, yang didasarkan pada rasa kasih dan sayang seorang suami-istri. Seseorang yang lahir dari suatu perkawinan yang sah,

\footnotetext{
10 Abdussalam ,Hukum Perlindungan Anak, (Jakarta: Restu Agung, 2007).
} 
Dewi Mulyati dan Ali Dahwir, Perlindungan Hukum Terhadap Anak Sebagai Pelaku Kejahatan, Halaman 31-48

maka terhadap anak tersebut dikatakan anak sah, dan sebaliknya disebut anak tidak sah. ${ }^{11}$

Pengertian anak dalam hukum Indonesia, masih belum memiliki keseragaman. Oleh sebab itu penulis telah merangkum beberapa pengertian anak dalam hukum Indonesia sebagaimana diuraikan di bawah ini:

- Pengertian anak berdasarkan pada Undang-Undang Nomor Tahun 1979 tentang perlindungan anak adalah orang yang berumur di bawah 21 tahun. dan tidak pernah kawin

- Undang-Undang Hak Asasi Manusia No. 39 Tahun 1999 mendefinisikan anak sebagai setiap manusia yang berusia di bawah 18 (delapan belas) tahun dan belum kawin, termasuk anak yang masih dalam kandungan apabila masih dalam kandungan status terbaiknya. minat.

- Adapuan Pengertian anak Nomor 23 Tahun 2002 Pasal 1 ayat (1) yang berkaitan dengan perlindungan anak hampir sama dengan Undangundang Nomor 39 Tahun 1999,

- Selain itu, Undang-undang Nomor 3 Tahun 1997 mengatur tentang

\footnotetext{
11 Abdussalam
}

sistem peradilan terhadap anak yang melakukan tindak pidana. Anak adalah mereka yang telah mencapai umur 8 (delapan) tahun akan tetapi belum pernah kawin.

- Selanjutnya pengertian anak dalam aspek hukum ketatanegaraan memiliki perberbedaan, misalnya hak untuk memilih dalam pemilihan. Seseorang dianggap dapat mempertanggung jawabkan perbuatan hukumnya pada saat ia mencapai usia 17 tahun (tujuh belas). Melihat pada ketentuan tersebut, maka dapat dikatakan bahwa penentuan batas usia anak relatif dan belum memiliki keseragaman. ${ }^{12}$

Selain itu, berdasarkan ketentuan dalam pasal 1 angka 2 Undang-undang Nomor 3 Tahun 1997 tentang sistem peradilan anak, maka anak yang melakukan kejahatan adalah anak yang melakukan tindak pidana dan anak yang perbuatannya dinyatakan sebagai perbuatan yang dilarang, baik menurut undang-undang maupun undang-undang lainnya. peraturan yang berlaku dan diterapkan di Ind onesia. ${ }^{13}$

\footnotetext{
12 Shanty Dellyanna, Wanita dan Anak di Mata Hukum ( Jogyakarta: Liberty, 2018).

13 Shanty Dellyanna
} 
Dewi Mulyati dan Ali Dahwir, Perlindungan Hukum Terhadap Anak Sebagai Pelaku Kejahatan, Halaman 31-48

Sesuai dengan pasal 1 angka 8 hukum bilangan. Desember 1995 sesuai dengan pasal 13 PP No. 31 Tahun 1999 tentang pembinaan warga negara yang didukung oleh masyarakat, terdapat tiga golongan siswa re-edukasi, yaitu anak kriminal, anak negara dan anak sipil sering.

Upaya pemerintah Indonesia memberikan perlindungan hukum terhadap hak-hak anak terbukti dengan telah banyak dibentuk aturan-aturan hukum untuk yang berfungsi penghormatan hak-hak anak. Hal ini seperti ratifikasi Konvensi Hak Anak (CRC) melalui Keputusan Presiden Nomor 36 tahun 1990. Terdapat Peraturan perundang-undangan yang lain tentang perlindungan anak yang dikeluarkan oleh pemerintah Indonesia diantaranya adalah Undang-Undang tentang sistem Pengadilan Anak yaitu Undang-undang Nomor 3 tahun 1997, Undang-Undang Hak Asasi Manusia Nomor 39 Tahun 1999, Undangundang Nomor 23 Tahun 2002 sebagaimana telah diubah dengan Undang-Undang Nomor 35 Tahun 2014 tentang Perlindungan Anak.

Apabila ditelaah secara substansi maka undang-undang tersebut mengatur tentang hak-hak anak, diantarana aturan tentang hak hidup, hak atas nama, hak untuk pendidikan, hak untuk perawatan kesehatan dasar, hak melaksanakan ibadah sesuai dengan kepercayaannya, hak berekspresi, berpikir, serta hak untukbermain, berkreativitas, hak istirahat, inklusi sosial serta jaminan sosial. ${ }^{14}$

Mengenai asas-asas hukum hak asasi manusia tentang perlindungan anak yang dituangkan pada instrumen hukum nasional dan internasional. terdapat berbagai ketentuan dalam hukum internasional yang mengatur tentang pelaksanaan perlindungan terhadap anak. misalnya seperti ang diatur dalam Konvensi Hak-hak, dimana konvensi Anak tersebut telah diratifikasi oleh pemerintah Indonesia.

Dengan telah diundangkannya UU No. 36 tahun 1990, artinya adalah Indonesia telah berkomitmen serta menjadi suatu kewajiban dalam rangka perlindungan hak anak. Adapun yang dimaksudakan dengan perlindungan anak, menurut Pasal 1 dan 2 UU Perlindungan Anak, adalah sebagai rangkaian kegiatan yang memiliki tujuan agar terjaminnya serta

14 Harkristuti Harkrisnowo, Tantangan dan Agenda Hak-Hak Anak (Jakarta,: Komisi Hukum Na sional, 2002). 
Dewi Mulyati dan Ali Dahwir, Perlindungan Hukum Terhadap Anak Sebagai Pelaku Kejahatan, Halaman 31-48

terlaksananya perlindungan anak seperti hak hidup, hak tumbuh dan berkembang, serta dapat berpartisipasi secara penuh dan konsisten yang memiliki harkat dan martabat sebagai manusia. Selain itu seorang anak juga mendapatkan perlindungan dari tindakan kekerasan dan tindakan diskriminasi. ${ }^{15}$

Dalam ketentuan Undang-undang Perlindungan Anak telah diatur mengenai asas serta tujuan pelaksanaan perlindungan anak, sebagaimana tercantum dalam Pasal 2 dan 3, sebagai berikut:

Pasal 2: Penyelenggara layanan perlindungan anak berdasarkan Pancasila dan Undang-Undang Dasar Negara Republik Indonesia Tahun 1945 serta asas-asas dasar Konvensi Hak Anak antara lain:

1. Tidak diperkenankan adanya sifat diskriminasi

2. Untuk kepentingan anak, harus diberikian yang terbaik terhadapo tumbuh kembang anak.

3. Perlindungan terhadap hak hidup, keberlangsungan hidup, serta perkembangan kondisi anak.

\footnotetext{
15 Waginati Soetedjo, Hukum Pidana Anak (Bandung: PT Refika Aditama, 2006).
}

4. Diberikan sutau penghargaan terhadap seorang anak.

Ketentuan dalam Pasal 3 Undangundang Perlindungan anak dinyatakan bahwa untuk menjamin terwujudnya hak-hak yang dimiliki oleh anak diantaranya hak hidup, hak tumbuh dan berkembang, serta hak untukberpartisipasi dengan optimal selaras pada harkat serta martabat manusia. Hak untuk dilindungi dari kekerasan serta tindakan diskriminasi yang diperlakukan untuk mencapai kehidupan yang berkualitas, berbudi luhur, mulia, dan sejahtera bagi anak Indonesia.

Dalam ketentuan Pasal 2 c telah ditegaskan bahwa hak untuk hidup, hak atas keberlangsungan hidup dan tumbuh kembang seorang anak merupakan implementasi hak asasi manusia yang paliing dasar yang di lindungi oleh negara, pemerintah, keluarga, dan orang tua, dan juga merupakan hak dasar sebagian besar manusia.

Perlindungan terhadap anak harus dilaksanakan oleh seluruh pihak, baik oleh orang tua sebagai yang terdekat, keluarga sebagai tempat tumpuan anak, masyarakat sebagai tempat anak 
Dewi Mulyati dan Ali Dahwir, Perlindungan Hukum Terhadap Anak Sebagai Pelaku Kejahatan, Halaman 31-48

bersosialisasi. Selain itu pihak pemerintah maupun Negara juga memiliki peran sentral dalam perlindungan tersebut. Didalam Pasal 20 UU No. 35 Tahun 2009 ditetapkan bahwa:

"Negara, pemerintah, masyarakat, keluarga dan orang tua memiliki kewajiban dan tanggung jawab untuk melaksanakan dan melindungi anakanak"

Pemerintah memiliki tanggungjawab serta wajib melakukan perlindungan terhadap anak sebagaimana diatur dalam UndangUndang PerlindunganAnak, seperti dibawah ini:

1. Menghormati serta memberikan jaminan terhadap hak-hak asasi semua anak, dengan tidak memandang suku bangsa, kepercayaan, warna kulit, golongan, gender, kebudayaan dan bahasa, statushukum, kelahiran spontan anak, serta bentuk fisik dan/ atau psikologi anak (Pasal 21);

2. Mendapatkan dukungan dalam bentuk sarana maupun prasarana dalam menyelenggarakan perlindungan terhadap anak (Pasal 22);

3. Memberikan jaminan dalam bentuk perlindungan, memelihara serta memberikan kesejahteraan terhadap anak, tetap konteks memberikan perhatian terhadap hak dan kewajiban orang tuanya, walinya maupun pihak lain yang secara bersama-sama memiliki tanggung jawab terhadap anak serta memberikan pengawasan dalampelaksanaan perlindungan terhad ap anak (Pasal 23);

4. Memastikan anak menggunakan haknya untuk berekspresi yang disesuaikan dengan umur serta tingkatan kecerdasan yang dimiliki oleh anak (Pasal 24).

Tanggungjawab perlindungan hak-hak anak tidak hanya menjadi milik pemerintah semata akan tetapi juga masyarakat memilikinya. Pelaksanaan perlindungan hak anak dapat dilakukan dengan kegiatan peran masyarakat dalam pelaksanaan perlindungan terhadap anak. (Pasal 25).

Sebagaimana diuraikan di atas bahwa perlindungan anak tidak hanya menjadi tanggungjawab negara akan tetapi keluarga sangat memiliki peran dalam upaya memberikan perlindungan terhadap anak. Hal ini sebagaimana diatur dalam Pasal 26 ayat (1) UndangUndang Perlindungan Anak, yaitu: pengasuhan, pemeliharaan, pendidikan, dan perlindungan, perlindungan anak; Membesarkan serta mendidik anak sesuai dengan kemampuan, bakat serta minat yang dimilikinya, selain itu kelurga juga memiliki tangggungjawab 
Dewi Mulyati dan Ali Dahwir, Perlindungan Hukum Terhadap Anak Sebagai Pelaku Kejahatan, Halaman 31-48

serta kewajiban untuk mencegah anak melakukan pernikahan dini.

Sebagaimana dikemukakan oleh Romli Atmasasmita sebagaimana dikutip oleh Wagianti Sutodjo, terdapat beberapa motivasi anak melakukan kejahatan, yaitu motif internal dan eksternal kenakalan anak seperti mengikuti keluarga. Sementara itu adapun yang tergolong pada motivasi ekstrinsik seperti faktor rumahtangga, faktor tingkat pendidikan disekolah, pergaulan anak, faktor media massa.

Beberapa faktor yang berbeda ini memberikan kemungkinan anak untuk melakukan tindakan yang melawan hukum, bahkan anak melakukan tindak pidana. Terhadap anak yang melakukan tindakan melawan hukum dalam bnertuk tindak pidana juga dapat dianggap sebagai anak yang melanggar hukum pidana. ${ }^{16}$

\section{Pelaksanaan} pemberian perlindungan untuk anak yang melakukan pelanggaran hukum, dapat dilakukan melalui sistem peradilan pidana anak. Dibutuhkan pemahaman yang lengkap tentang hal ini yang bukan hanya tentang pengasuhan anak. Namun demikian, pelaksanaan sistem

16 Wagiati Soetodjo peradilan pidana anak juga harus dapat diartikan sebagai suatu usaha mencari faktor penyebab terjadinya kejahatan anak serta bagaimana tindakan yang dilakukan dalam upaya pencegahannya. Selain itu, kompetensi sistem peradilan pidana anak mengakomodir banyak permasalahan anak, seperti eksposur anak ke polisi, proses pengadilan, kondisi penahanan dan persidangan ulang, inklusi sosial, termasuk pelaku dalam prosesnya. Oleh karena itu, istilah sistem peradilan pidana anak mengacu pada undang-undang, norma dan aturan tertentu, prosedur, mekanisme dan pengaturan, lembaga dan badan yang secara khusus yang berfungsi untuk melakukan proses peradilan kepada anak sebagai pelaku tindak pidana. ${ }^{17}$

Pada dasrnya pelaksanaan upaya perlindungan hukum terhadap anak juga merupakan upaya pelaksanaan hukum itu sendiri. sehingga pelaksanaannya juga dapat dipengaruhi banyak sebab, diantaranya:

1. Peraturan Perundang-undangan. Perundang-undangannya termasuk substansi undangundang maupun struktur

17 Ana Volz,Advocacy Stratgis Training Manual-General Coment No.10 Children"s Right in juvenile justice, Defence For Children Internasional, 2009. 
Dewi Mulyati dan Ali Dahwir, Perlindungan Hukum Terhadap Anak Sebagai Pelaku Kejahatan, Halaman 31-48

hukumnya. Dalam hal ini, pertanyaan tentang ketentuan hukum yang berkaitan dengan hak anak atas metode pelatihan dan persyaratan hukum pelatihan mereka, serta pertanyaan apakah semangat hukum, nilai-nilai, prinsipprinsip hukum atau tidak. atau aturan serta sanksi hukum yang diinginkan dan aturan pelaksanaannya harus disiapkan agar tidak terjadi kesenjangan hukum.

2. Aparat penegak hukum, yaitu advokat atau organisasi yang terlibat dalam kontinum penerapan hukum didalam masyarakat. Mengenai mekanisme penegakan hukum di Indonesia, struktur penegakan hukum yang disebut Catur Wangsa terdiri dari kepolisian (lembaga penyidik), kejaksaan (jaksa), kehakiman (peradilan) serta advokat atau biksu. Pemajuan hak-hak anak dan penegakan hukum anak, dalam konteks banyak permasalahan yang muncul di Indonesia, membatasi aktivitas aparat penegak hukum dalam memahami hukum dan hak-hak anak, kualitas pendidikan pendidikan dan keahlian masing-masing aparatur eksekutif. Selain itu, kemampuan organisasi untuk penegakkan hukum terhadap anak serta perlindungan terhad ap hak-hak anak.

3. Cara bagaimana bentuk budaya hukum masyarakat, khususnya stratifikasi sosial dan sikap berbudaya hukum, bagaimana masyarakat memandang tentang penegakan hukum yang merupakan pedoman perilaku sehari-hari yayng harus dituruti. Isu tentang budaya hukum tidak dapat ditapikkan dalam rangka penegakan hukum diIndonesia, hal ini menyangkut kepercayaan masyarakat terhadap hukum dan penegakan hukum.

4. Masyarakat hukum. Masyarakat sebagai tempat hukum tumbuh dan berkembang yang bersamasama dengan proses perkembanga kehidupan seharihari, meliputi tingkat kepatuhan masyarakat terhadap hukum, minat masyarakat terhadap hukum terhadap ketertiban dan ketentraman. Hormati hak anak dalam kehidupan sehari-hari. UU perlindungan tentang Anak hanyalah sebagai panduan yang dapat dijadikan instrumen untuk melakukan perlindungan yang seharusnya dilakukan oleh masyarakat apabila ditemukan terjadi permasalahan anak. ${ }^{18}$

Berdasarkan ketentuan dalam Pasal 22 Undang-Undang Nomor 3 Tahun 1997, bagi anak yang berbuat jahat hanya dapat dituntut atau dilakukan tindakan. Selanjutnya mengenai penerapan hukuman terhadap anak yang melakukan tindak pidana dapat berupa tindak pidana atau perbuatan. Sanksi yang dapat dikenakan adalah:

\footnotetext{
18 Moch. Jony dan Zulchaini, Aspek Hukum Perlindungan Anak (Bandung: ,PT. Citra Aditya Bhakti, 1999).
} 
Dewi Mulyati dan Ali Dahwir, Perlindungan Hukum Terhadap Anak Sebagai Pelaku Kejahatan, Halaman 31-48

1. Sanksi Pidana pokok serta sanksi pidana tambahan.

2. Ditetapkan jenis Pidana pokok yang dapat diberikan kepada anak nakal adalah hukuman penjara, hukuman kurungan, hukuman denda, dan hukuman pengawasan.

3. Selain daripada hukuman pokok kepada anak nakal hakim juga dapat menjatuhkan hukuman tambahan dalam bentuk perampasan beberapa barang tertentu serta pembayaran ganti kerugian.

4. Selanjutnya aturan mengenai cara dan prosedural pelaksanaan pembayaran ganti kerugian ditetapkan lebih lanjut dengan peraturan pemerintah.

Secara bertahap jenis-jenis pidana bagi anak diatur dalam pasal 6973 Undang-Undang Nomor 11 Tahun 2012, jika lebih rinci pidananya merupakan hukumsn pokok dan hukuman pelengkap.

1. Hukuman pokok terhadap Anak adalah:

a. hukuman peringatan;

b. hukuman dengan persyaratan:

1) dibina oleh negara diluar lembaga;

2) memberikan pelayanan kepada masyarakat; atau

3) dilakukan pengawasan.

c. dilatih bekerja;

d. dibina oleh negara dalam lembaga; dan

e. dimasukkan dalam penjara.

2. Hukuman tambahan yaitu:
a.Negara merampas keuntungan yang didapat dari tindakan pidana; atau

b. Pemenuhan kewajiban adat.

3. Jika hukum substantif diancam dengan sanksi kumulatif berupa pidana penjara dan denda, denda diganti dengan pelatihan vokasi.

4. Hukuman terhadap terhadap Anak tidak boleh melanggar harkat serta martabat Anak.

5. Ketentuan untuk lebih lanjut tentang bagaimana bentuk serta prosedur pelaksanaan pidana dalam ayat (1), ayat (2), dan ayat (3) akan diaatur melalui Peraturan Pemerintah.

Mengenai Tindakan diatur dalam Pasal 82 Undang-Undang Nomor 11

Tahun 2012 yang terdiri dari:

(1) Adapun tindakan yang bisa diberikan terhadap Anak adalah:

a. dikembalikan ke orang tua/Wali;

b. diserahkan kepada seseorang;

c. dilakukan perawatan dirumah sakit jiwa;

d. dilakukan perawatan oleh LPKS;

e. diwajibkan untuk ikut dalam pendidikan formal dan/atau pelatihan yang dilaksanakan pemerintah dan atau dilaksanakan oleh badan swasta;

f. dicabutnya surat izin mengemudi; dan/atau

g. pemulihan kembali akibat tindak pidana

(2) Tindakan sebagaimana dimaksud pada ayat (1) huruf d, huruf e, dan 
Dewi Mulyati dan Ali Dahwir, Perlindungan Hukum Terhadap Anak Sebagai Pelaku Kejahatan, Halaman 31-48

huruf f dikenakan paling lama 1 (satu) tahun.

(3) Tindakan sebagaimana dimaksud pada ayat (1) dapat diajukan oleh Penuntut Umum dalam tuntutannya, kecuali tindak pidana diancam dengan pidana penjara paling singkat 7 (tujuh) tahun.

(4) Ketentuan lebih lanjut mengenai tindakan sebagaimana dimaksud pada ayat (1) diatur dengan Peraturan Pemerintah

Ketentuan ini bisa ditemukan dalam Undang-Undang Nomor 23 Tahun 2002 sebagaimana telah diubah dengan Undang-Undang Nomor 35 Tahun 2014 tentang Perlindungan Anak dalam Pasal 17 ayat (1), secara khusus bahwa setiap anak yang dirampas kemerdekaannya berhak atas:

a. Diperlakukan secara manusiawi dan terpisah dari orang yang sudah dewasa.

b. Mendapatkan bantuan hukum maupun bantuan dalam bentuk lain besifat efektif pada setiap tingkatan upaya hukum yang ada, seperti konseling pekerjaan sosial, konseling psikologi dan psikiater, atau dukungan ahli bahasa.

c. Mendapatkan pembelaan diri serta mendapatkan keadilan dalam proses pengadilan anak bersifat objektif dan tanpa memihak pada serta dilaksanakan tertutup untuk umum.

Anak sebagai pelaku kejahatan lebih mudah dikendalikan dan diremediasi apabila dibandingkan dengan orang dewasa sebagai pelaku kejahatan. Hal ini dikarenakan tingkat perkembangan anak berbeda dengan karakteristik dan kepribadian anak. Bayi, remaja, dewasa dan orang tua berbeda secara psikis dan fisik. Sistem peradilan pidana yang mengatur sanksi pidana pendidikan/ pendidikan selama ini jarang ditegakkan oleh aparatur penegak hukum diIndonesia, khususnya para hakim. MIsalnya sanksi pidana pendidikan adalah diberiannya sanksi pidana yang bukan hanya mengembalikan kepada orang tua/wali atau lingkungan, akan tetapi sanksi pidana tersebut mengandung tujuan pendidikan, seperti menyekolahkan mereka ke pondok pesantren bagi pelaku yang beragama Islam, atau mengirim mereka ke gereja untuk umat kristen yang beragama islam dan organisasi keagamaan lainnya yang sesuai dengan agama yang dianut atau dianut.

Pelaksanaan pemidanaan secara individu yang telah dilaksanakan selama ini adalah suatu upaya pencegahan terjadinya kejahatan yang terfragmentasi yang mempertimbangkan upaya pencegahan hanya dari perspektif individu. 
Dewi Mulyati dan Ali Dahwir, Perlindungan Hukum Terhadap Anak Sebagai Pelaku Kejahatan, Halaman 31-48

Sedangkan upaya pemecahan permasalahan anak bukan hanya dapat dilihat secara pengelolaan individu anak, akan tetapi dapat juga ditinjau dari beberapa faktor, yang salah satunya adalah bagaimana cara agar anak tidak kembali melakukan perbuatan melanggar akan tetapi juga merupakan keteladanan serta pendidikan yang baik bagi generasi muda. Hal ini bertujuan untuk mendidik jiwa spiritual anak agar perilaku menyimpang anak ini menjadi lebih baik lagi.

Menempatkan anak sebagai penjahat dalam lembaga pemasyarakatan tidak akan dapat memberikan jaminan bahwa anak tersebut akan berubah menjadi lebih baik, karena didalam lembaga pemasyarakatan sudah tidak ditemukan lagi upaya perbaikan budi dan jiwa anak tersebut secara baik, karena mereka merupakan orang-orang yang diasingkan bersama para pelaku kejahatan yang lain, itu mempromosikan pemulihan. Perilaku anak ke arah yang lebih baik seringkali terhambat oleh lingkungan yang kurang baik di dalam lembaga pemasyarakatan itu sendiri.
Lain halnya jika Anda menempatkan anak di lingkungan yang tidak merasa diperlakukan seperti penjahat, tetapi memperlakukannya seperti layaknya anak-anak yang belum dewasa yang belum memahami serta belum mengetahui mbanyak hal. Oleh karena itu seorang anak masih membutuhkan bimbingan, diorientasikan dan diajarkan tentang perbuatan baik dan buruk. selanjutnya memberdayakan mereka yang pernah terlibat dalam suatu tindak pidana dalam pelaksanaan hukum serta pelaksanaan pidananya. Hal ini berfungsi untuk mengklasifikasikan mereka sebagai penjahat muda yang karakteristiknya berbeda dengan penjahat dewasa.

Padahal, sistem hukuman pendidikan seperti ini bukanlah hal baru. Dalam Undang-Undang Nomor 11 Tahun 2012 tentang Peradilan Anak jelas berkaitan dengan sistem pendidikan pidana, namun dalam penerapannya hal ini jarang dilakukan, tidak heran bila anak-anak ini dengan paksaan belum diasuh. mengkhusu skan diri dalam menangani kasus-kasus di bidang anak-anak dan kadang-kadang juga mengambil posisi, mengutuk baik anak-anak maupun orang dewasa. 
Dewi Mulyati dan Ali Dahwir, Perlindungan Hukum Terhadap Anak Sebagai Pelaku Kejahatan, Halaman 31-48

Tujuan diberikannya

perlindungan hukum terhadap pelaku kejahatan merupakan bentuk penghormatan terhadap hak asasi pencipta agar tidak terhenti kebebasannya, kepastian hukum bagi pelaku, dan dalam rangka menghindari penuntutan, tindakan kesewenangan yang tidak memberikan rasa adil. Sementara itu konsep perlindungan terhadap anak memiliki cakupan yang luas, dimana perlindungan terhadap anak tidak terbatas pada perlindungan jiwa serta raga anak, akan tetapi termasuk juga didalamnya upaya perlindungan terhadap segala hak dan kepentingan yang dijamin agar anak dapat berkembang secara wajar baik mentalnya. Secara fisik dan sosial perlindungan tersebut diharapkan agar anak menjadi orang dewasa yang produktif. 19

Terkhusus terhadap anak yang berkonplik dengan hukum, menurut ketentuan Pasal 6 ayat (1) UU Perlindungan Anak ditujukan kepada anak yang melanggar hukum dan anak yang menjadi korban tindak pidana. Berdasarkan Pasal 6 Ayat (2) UU

19 Dwi H. Retnaningrum ,Manunggal K.Wardana, Perlindungan Terhadap Anak Yang Melakukan Tindak Pidana, (Artikel Dosen Universitas Surabaya, 2010).
Perlindungan Anak, maka perlindungan anak di hadapan hukum dilakukan melalui:

1. Anak diperlakuan dengan manusiawi yang disesuaikan dengan martabat serta hak-hak sebagai anak;

2. Disediakannya sarana-sarana serta prasarana-prasarana secara khusus;

3. Disediakannya petugas khusus yang akan mendampingi anak sedari dini ;

4. Peninjauan serta hasil dari peninjauan itu senantiasa dicatat secara berkesinambungan dalam rangka mengetahui perkembangan seorang anak yang berkonflik dengan hukum;

5. Mendapatkan jaminan dari negara dalam mempertahankan hubungan anak dengan orang tua atau keluarganya.

6. Seorang anak dilindungi atas pemberitaan jati diri melalui media-media yang ada dalam rangka untuk menghindari tind akan labelisasi.

Salah satu masalah besar dengan hukuman anak adalah efek negatif hukuman pada perkembangan anak. Hukuman sering kali meninggalkan bekas yang salah pada seseorang, yang dalam keadaan anakanak bisa sangat merusak kehidupan mereka yang telah lama diharapkan. Penyelesaian non-kriminal adalah ide awal dan sering lebih disukai oleh para pihak. Di pihak pelaku, stigma dapat dihindari, sedangkan korban akan 
Dewi Mulyati dan Ali Dahwir, Perlindungan Hukum Terhadap Anak Sebagai Pelaku Kejahatan, Halaman 31-48

memperoleh kepuasan dari kompensasi dan/atau kesepakatan dengan pelaku. Bukannya dihukum, pelakunya dikembalikan ke orang tuanya, sedangkan korban, misalnya, diberi kompensasi dan minta maaf. Meskipun penyelesaian non-kontroversial tidak selalu disetujui oleh korban, terutama oleh korban, jenis penyelesaian ini terbukti banyak dipilih oleh pihakpihak yang berkonflik.

\section{KESIMPULAN}

Perlindungan hukum terhadap anak merupakan tindak pidana dengan lahirnya sejumlah undang-undang yang bertujuan untuk melindungi anak yang melakukan tindak pidana khususnya UU No. 11 Tahun 2012 tentang Sistem Peradilan Anak.

Dalam Undang-Undang tersebut telah diatur tentang bagaimana bentuk perlindungan hukum terhadap anak yang melakukan kejahatan.Bentuk perlindungan terhadap anak diberikan pada setiap tahapan proses peradilan pidana anak. Mulai dari tahapan penangkapan, tahapan penahanan, tahappenyidikan, penuntutan, maupaun tahap persidangan serta pada masa pembinaan. Bentuk perlindungan lainnya adalah diatur juga mengenai upaya penyelesaian perkara tindak pidana diluar persidangan yakni perkara anak senantiasa diupayakan melalui diversi dan hal ini diwajibkan dilakukan upaya pada setiap tahapan proses peradilan pidana anak.

Tujuan pemberian perlindungan hukum kepada anak pelaku kejahatan juga merupakan implementasi penghormatan hak asasi pelaku supaya psikologisna tidak terganggu, mempunyai kepastian hukum, serta untuk menghindari perlakuan yang sewenang-wenang dan tidak adil.

\section{DAFTAR PUSTAKA}

A. A. Raden Cahaya Prabu, Perkembangan Taraf Inteligensia Anak, Bandung: Angkasa, 2011.

Abdussalam, Hukum Perlindungan Anak, Jakarta: Restu Agung, 2007.

Ana Volz,Advocacy Stratgis Training Manual-General Coment No.10 Children"s Right in juvenile justice, Defence For Children Internasional, 2009.

Dwi H. Retnaningrum ,Manunggal K.Wardana, Perlindungan Terhadap Anak Yang Melakukan Tindak Pidana, Artikel Dosen Universitas Surabaya, 2010.

Gatot Supramono, Hukum Acara Pengadiilan Anak, Jakarta: Djambatan, 2007. 
Dewi Mulyati dan Ali Dahwir, Perlindungan Hukum Terhadap Anak Sebagai Pelaku Kejahatan, Halaman 31-48

Harkristuti Harkrisnowo, Tantangan dan Agenda Hak-Hak Anak, Jakarta,: Komisi Hukum Nasional, 2002.

Marjan Haposanda Sinaga, Proses Peradilan Pidana Anak Yang Berkonflik Dengan Hukum Dalam Rangka Pemberian Perlindungan Hukum Terhadap Anak, Skripsi Fakultas Hukum Dan Komunikasi, Semarang: Unika Soegijapranata 2018.

Media Akademika,Volume 26 Nomor 2 April 2011

Moch. Jony dan Zulchaini, Aspek Hukum Perlindungan Anak, Bandung: PT. Citra Aditya Bhakti, 1999.

Serafina S.D, Perlindungan Hak Anak Pelaku Kejahatan Dalam Proses Peradilan, Yogyakarta: Kantor Kementerian Hukum dan HAM, 2011.

Shanty Dellyanna, Wanita dan Anak di Mata Hukum, Jogyakarta: Liberty, 2018.

Waginati Soetedjo, Hukum Pidana Anak, Bandung: PT Refika Aditama, 2006.

Zakiah Darajat, Faktor-faktor Yang Merupakan Masalah Dalam Proses Pembinaan Generasi Muda, Kertas Kerja Pada Simposium Aspek-Aspek Hukum Masalah Perlindungan Anak .Dilihat Dari Segi Pembinaan Generasi Muda, Jakarata: DepHam RI, 1980. 